\title{
Een slachtoffer heeft JHWH in het Noorderland (Jer 46:10)
}

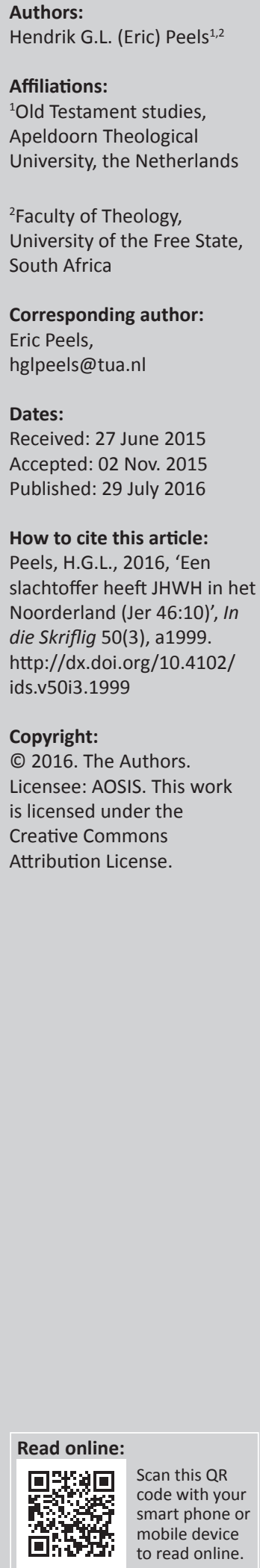

For the Lord will offer sacrifice in the land of the North (Jer 46:10). The present article 'For the Lord will offer sacrifice in the land of the North (Jer 46:10)' combines two focal points of my research, namely the issue of the Old Testament image of God and the interpretation of the book of Jeremiah. In Jeremiah 46:2-12, the first oracle against Egypt sketches a frightening picture of the destruction of Egypt's army, which was crushingly defeated by the Babylonians at Carchemish. The destruction is represented as a sacrificial meal, at which the divine sword feasts on the flesh and the blood of God's enemies. In order to adequately understand the purport of his prophetic interpretation, I present a contextual exegesis of the pericope. It is read in its literary context and against its historical background. After a concise analysis of its structure and a detailed exegesis of the pivotal verse (46:10), I conclude with a theological evaluation concerning the meaning and significance of this eerie prophecy.

\section{Een hommage aan prof. Jordaan}

Het is een voorrecht en vreugde om te mogen bijdragen aan het Festschrift voor prof. Jorrie Jordaan die ik in de vele jaren van contact tussen onze theologische instellingen te Potchefstroom en te Apeldoorn als een bekwame en hartelijke collega heb leren kennen. Als geschenk bied ik hem in dit artikel een vrucht van mijn wetenschappelijk onderzoek, dat zich langs twee lijnen beweegt: het godsbeeld van het Oude Testament (theologisch onderzoek) en de interpretatie van het boek Jeremia (exegetisch onderzoek). Beide lijnen kruisen elkaar in een tekst als Jeremia 46:10 die een huiveringwekkend beeld schetst van een offermaaltijd waarbij het goddelijk zwaard vijanden verslindt en dronken wordt van het bloed van de vijand. Dit artikel bevat een contextuele exegese van dit vers, met achtereenvolgens paragrafen over de literaire plaatsbepaling van de profetie waarin dit tekstvers staat, de historische achtergrond van deze profetie, de structuur van de profetie, een detailexegese van Jeremia 46:10 en een beknopte theologische evaluatie.

\section{Literaire plaatsbepaling van de profetie}

De bundel volkenprofetieën van Jeremia 46-51 MT opent met een profetie tegen Egypte in Jeremia 46. Met betrekking tot de samenstelling en structuur van dit caput worden geheel verschillende standpunten ingenomen. Het hoofdstuk lijkt een assemblage te zijn van allerlei korte profetieën, zowel in poëzie als in proza, met Egypte als centraal thema. De meeste uitleggers zijn echter van mening dat dit hoofdstuk twee grotere samengestelde gedichten bevat (vss 2-12 en vss 13-24/26), met een of twee aanvullingen (vss 25-26, vss 27-28) aan het slot. Sommigen opteren voor $\mathrm{x}$-aantal oorspronkelijk zelfstandige tekstfragmenten, maar geven daarbij wel aan dat deze bestemd zijn om 'samengelezen' te worden in de grotere eenheden van Jeremia 46:2-12 en Jeremia 46:13-24 (zo bijv. Lundbom 2004:185; De Jong 1978:93-115). De twee gedeelten 46:2-12 (thema: Egypte's offensief gekeerd) en 46:13-26 (thema: Egypte's defensief gebroken) hebben elk een eigen opschrift, dat gekoppeld is aan een directe historische verwijzing. Dat binnen hetzelfde hoofdstuk een tekstuele overgang op deze wijze gemarkeerd wordt, is in de bundel van Jeremia 46-51 uniek. Huwyler (1997:75) ziet hierin een aanwijzing dat de redactor twee zelfstandige, afgesloten teksteenheden (vss 2-12 en vss 13-24) heeft samengevoegd.

Zoals bekend staat de bundel volkenprofetieën in de Griekse versie van Jeremia op een andere plaats, namelijk in het midden van het boek, in aansluiting op Jeremia 25:1-13 LXX. De bundel heeft in de Septuaginta ook een andere volgorde, openend met een profetie tegen Elam (Jer 25:14-19 LXX) met daarna die tegen Egypte (Jer 26 LXX). Omstreden is de vraag welke ordening van de volkenprofetieën de meest originele is, die van MT of die van LXX. Het antwoord op deze vraag hangt uiteraard mede af van het standpunt dat men inneemt ten aanzien van de prioriteit van de Griekse kortere of de Hebreeuwse langere tekst van Jeremia. 
Feit is wel dat in de Masoretische ordening de profetie tegen Egypte veel meer dan in de Septuaginta een passende en functionele plaats heeft, en wel in drie opzichten. Ten eerste in chronologisch opzicht, omdat deze profetie die in 605 of kort daarna gedateerd kan worden, de oudste van de hele bundel is. De profetieën die volgen bieden tezamen een beeld van de periode na 605 , toen Babel aan de toenmalige wereld zijn wil oplegde, en dateren uit die tijd. Ten tweede in boekstructureel opzicht, omdat deze profetie goed aansluit bij de gebeurtenissen die in de direct voorgaande capita verhaald zijn: de ondergang van Juda en de wanhoopsvlucht naar Egypte (Jer 43:7), de profetie over de verovering van Egypte door Nebukadnessar (Jer 43:8-13) en de hernieuwde afgoderij door Juda in Egypte (Jer 44). Het oordeel door JHWH aangekondigd over al wat leeft (Jer 45:5), begint dichtbij: in het toevluchtsoord van de valse hoop, Egypte. Deze volgorde wordt ook aangehouden in de zogenaamde bekerperikoop (Jer 25:15-29), waar beschreven wordt dat na Juda Egypte als eerste van de volken de beker zal moeten drinken. In de derde plaats in theologisch opzicht, omdat de profetische waarschuwing tegen vertrouwen op Egypte die door het hele boek Jeremia heen te vinden is hiermee tot een climax komt: aan Egypte is geen enkele hoop meer te ontlenen. Terecht stelt Brueggemann dat het oordeel over Egypte in het boek Jeremia overwegend negatief is: 'Egypt is a primary cipher for all that resists the purposes of Yahweh' (1998:454). Dit wordt door de positionering van de profetie tegen Egypte aan het begin van de bundel volkenprofetieën nog eens extra onderstreept, zoals uitgelegd door Maier (2002):

Das Gericht, mit dem JHWH seine unangefochtene Oberherrschaft über die Nationen demonstriert, 'muss' bei Ägypten beginnen, weil die Judäer auf es ihre Hoffnungen gesetzt und es zu einer quasi-göttlichen theo-politischen Alternative gemacht haben. (blz. 277)

\section{Historische achtergrond en authenticiteit van de profetie}

Het opschrift van de eerste profetie over Egypte (Jer 46:3-12) voorziet de lezer van precieze namen, locatie en datering. Waar in ouder onderzoek deze data soms nog omstreden waren, is dat sinds de publicatie van de Babylonische Kroniek door Wiseman in 1956 niet langer het geval. Jeremia 46:2 verwijst naar de slag bij Karkemiš in 605 v.Chr., een veldslag die een keerpunt in de geschiedenis van het oude Nabije Oosten teweegbracht. Inhoudelijk weerspiegelt de profetie van Jeremia 46:3-12 treffend wat zich voorafgaand aan en volgend op deze slag heeft afgespeeld (Barstad 2012:89-93): de snelle opmars van het Egyptische leger naar het noorden, de verpletterende nederlaag bij de Eufraat en de smadelijke vlucht van een restant naar het zuiden. Over de slag bij Karkemiš worden we naast het Oude Testament ook geïnformeerd door de Babylonische Kroniek en door passages bij Flavius Josephus (met name Antiquitates 10.84-86). De getuigenissen stemmen verregaand overeen (voor een breed verslag van de gebeurtenissen in het decennium rond 605 v.Chr., zie Wiseman 1956:13-32; Redford 1992:447-460; Lipschits 2005:32-42).
Na de ondergang van het Nieuw-Assyrische rijk in de laatste decennia van de 7e eeuw v.Chr. stonden bij de Eufraat de twee toenmalige wereldmachten tegenover elkaar: Egypte en Babylonië. In de jaren tussen 609 en 605 v.Chr. had farao Neko met wisselend succes zijn invloed in Noord-Syrië geconsolideerd vanuit zijn hoofdkwartier in het belangrijke steunpunt Karkemiš. De strijd aan de bovenloop van de Eufraat ging heen en weer, totdat in 605 v.Chr. Nebukadnessar II een rechtstreekse aanval op Karkemiš lanceerde. Hij versloeg daar in een verbitterde strij ${ }^{1}$ het Egyptische leger dat inmiddels was toegesneld om de garnizoenstroepen te versterken. De slag kan tamelijk precies gedateerd worden: juni-juli 605 v.Chr. (Wiseman 1985:16). Na een achtervolging vernietigde Nebukadnessar de vluchtende Egyptenaren in het land van Hamath, en breidde daarna zijn territorium aanzienlijk uit. De slag bij Karkemiš heeft de poort naar het zuiden voor 'de vijand uit het noorden' definitief geopend; de impact van de Babylonische overwinning in die dagen kan moeilijk overschat worden. Voor Juda had deze afloop grote gevolgen. Niet lang daarna zal koning Jojakim zich als vazal aan Nebukadnessar hebben onderworpen (in 604 v.Chr.; vgl. 2 Kon 24:1; zie ook Lipschits 2005:46).

De tekst van Jeremia 46:3-12 laat zich het beste lezen als een retrospectief profetisch commentaar op de slag bij Karkemiš, een strijd die een verpletterende indruk heeft gemaakt op de volkenwereld van die dagen. Een mogelijke aanwijzing hiervoor is ook dat Nebukadnessar in 46:2 expliciet 'koning' wordt genoemd, een titel die hij ruim drie maanden na de slag bij Karkemiš bij zijn officiële troonsbestijging te Babylon ontving. Kessler vergelijkt Jeremia 46:3-12 met gelijksoortige 'Katastrophenschilderungen' in Jesaja 10:28-32, Jeremia 48:1-8, Micha 1:10-16 en Nahum 2:2-11, en stelt terecht dat het in dit soort teksten niet gaat om toekomstvoorzeggingen (2002:50). Het feit dat het opschrift van 46:2 op het verleden ziet (הכה 'verslagen heeft') en het opschrift van 46:13 op de toekomst (לבוא ... להכות 'om te komen ... om te verslaan') past hier goed bij. Zo vormen de beide profetieën van Jeremia 46 een tweeluik: zoals JHWH in het verleden met Egypte gehandeld heeft, zal Hij dat ook in de nabije toekomst doen. Zo zeker als Egypte op vreemde grond verslagen is, zal het op eigen grond verslagen worden.

Hoe groot in de geschiedenis van het onderzoek de neiging ook geweest is om allerlei (delen van) volkenprofetieën aan de profeet Jeremia zelf te ontzeggen, de perikoop 46:3-12 vormt hierop een uitzondering. De meeste exegeten ontdekken in deze tekst genuïen jeremiaanse taal en motieven: 'This oracle has greater claim to authenticity than any other in the collection' (Hyatt 1956:1105; vgl. Lundbom 2004:182; Allen 2008:461; Bright 1965:308; Holladay 1989:318; Van der Westhuizen 1991:85). Geregeld wordt in dit verband ook gewezen op parallellen tussen de profetie over Egypte in Jeremia 46:3-12 en Jeremia's oordeelswoorden tegen Juda in Jeremia 2-6. In zijn minutieuze monografie over Jeremia 46-49 hanteert Huwyler de tekst van Jeremia 46:3-12 zelfs als uitgangspunt en criterium voor de vaststelling van het 1.Archeologische vondsten tonen hiervan de duidelijke sporen (Wooliey 1921:125-128). 
jeremiaanse auteurschap van de andere teksteenheden (1997:36). Overigens laat deze tamelijk eensgezinde overtuiging inzake het jeremiaanse auteurschap van Jeremia 46:3-12 de mogelijke aanwezigheid van kleinere secundaire elementen onverlet.

\section{Structuur en inhoud van de profetie}

De eerste profetie tegen Egypte (Jer 46:3-12) kenmerkt zich door staccato, meeslepend taalgebruik en onverwachte overgangen. Het is niet verwonderlijk dat exegeten met hun voorstellen voor een tekststructuur tot geheel verschillende resultaten zijn gekomen. Duidelijk is dat de profetie wordt ingeleid door een dubbel opschrift in vers 2 en afgesloten in vers 12, waarna in vers 13 met een nieuw opschrift de tweede profetie tegen Egypte (Jer 46:14-26) opent. De profetie van Jeremia 46:3-12 wordt door een kleine meerderheid van de exegeten ingedeeld in drie strofen (3-6 // 7-10 // 11-12; zo Rudolph 1958:248; Weiser 1956:390-392; Jones 1992:492-493; Snaith 1971:23; Jackson 1993:137-138; Huwyler 1997:78; Maier 2002:278). Veel andere voorstellen zijn gedaan voor een indeling in twee, vier, vijf, zes en zelfs zeven strofen. Naar het oordeel van Fretheim gaat het in deze perikoop om 'a complex collage' met een duidelijke boodschap maar zonder enige logische of chronologische helderheid (2002:625). Terecht stelt echter Huwyler: 'Die „Unordnung" des Textes ist sicherlich beabsichtigt, spiegelt sie doch die Unordnung der dargestellten Situation, das über das ägyptische Heer hereinbrechende Chaos` (1997:94). De onverwachte wendingen en perspectiefwisselingen in deze profetie zijn geen signaal van een corrupte tekst, maar een subtiel stijlmiddel in een communicatieve strategie die de lezer/ hoorder wil committeren.

Naar mijn mening vormt de eerste Egypte-profetie Jeremia 46:3-12 beslist geen onsamenhangend geheel, maar is er een interne dynamiek waarmee de spanning in drie fasen wordt opgebouwd (Peels 1995:178; een soortgelijke argumentatie bij Höffken 1977:266-267 en Huwyler 1996:198-199; 1997:78, 94-96). Binnen dit drieluik tekenen de verzen 46:3-6 in contrast de voorbereiding tot een veldslag (de commando's) en de afloop ervan (de wilde vlucht). De lezer/hoorder blijft achter met de vraag over wie het gaat en naar de reden van deze onverwachte afloop. Hierop haakt Jeremia 46:7-10 in. Deze verzen geven een verdieping van de eerste strofe door uit te leggen wie zich zo voorbereidde (46:7-9) en Wie deze afloop veroorzaakte (46:10). Voor de tweede maal - maar nu is het duidelijk om wie het gaat - klinken de commando's aan het leger dat straks bij de Eufraat gestopt wordt (46:9 resp. 46:10). Tenslotte vormt 46:11-12 de afsluiting met een tekening van de rampzalige gevolgen voor de verliezer - geen genezing en wereldwijde jammer. Het samenspel van deze drie delen wordt versterkt door de link tussen de concluderende slotwoorden van elk deel ('Eufraat' en 'struikelen/vallen' in 46:6, 'Eufraat' in 46:10 en 'struikelen/vallen' in 46:12; Snaith 1971:23), en door een netwerk van sleutelwoorden en motieven (Bourguet 1987:148-149).
Jeremia 46:3-12 biedt inhoudelijk een meeslepende tekst die spreekt tot de verbeelding van de hoorder/lezer. Snelle commando's weerklinken, suggestieve lacunes in het beschrevene prikkelen tot nadenken, evenals verbaasde vragen en de herhaling van scènes. De levendige voordracht van een dergelijke tekst moet op de hoorders grote indruk hebben gemaakt.

In de eerste strofe (46:3-6) worden climax en anticlimax op pakkende wijze gebundeld. De spanning hangt in de lucht als de bevelen klinken (46:3-4): hier maakt een machtig leger zich gereed voor de slag. In de korte opeenvolgende zinnen klinkt een haastige gejaagdheid door: alles moet voor de opmars gereed worden gemaakt. Lichte en zware infanterie treden aan, krijgswagens met briesende paarden trekken op. Totaal onverwachts verschuift het beeld naar de paniek waarmee ditzelfde leger, compleet verslagen, zich wanordelijk terugtrekt. Hoe is dit mogelijk, wat gebeurt hier toch (46:5a)? Dit is niet meer te stuiten: 'schrik van rondom!' luidt het commentaar van Godswege (46:5b).

In de tweede strofe (46:7-10) krijgt de hoorder/lezer een helderder beeld, zowel van het oprukkende en even later wegvluchtende leger als van de oorzaak van deze plotselinge omkeer. Het leger dat triomferend optrekt ten strijde, gelijk de Nijl die buiten zijn oevers treedt (46:7), is dat van Egypte. Farao Neko maakt zich breed om de wereld te veroveren en wie hij op zijn pad vindt te vernietigen (46:8). Zijn leger, dat met commando's wordt aangevuurd, bevat grote contingenten hulptroepen, beroemd om hun krijgsmanschap en militaire kwaliteiten (46:9). Maar de dag dat Neko zijn triomfen wil behalen is de dag van JHWH's wraak (46:10). Bij de Eufraat wordt de vloed van de Nijl definitief gekeerd. De naam van Babel of Nebukadressar wordt er niet eens bij genoemd, de eigenlijke Tegenstander - met wie Neko niet gerekend had is JHWH zelf, die een einde maakt aan deze godvergeten machtsgreep. Met de huiveringwekkende metafoor van een offerfeest, waarbij het zwaard van JHWH als gast zich tegoed doet aan de maaltijd, wordt Egypte's ondergang plastisch verbeeld (46:10).

Wat van Egypte rest, wordt ironisch aangespoord medicijn en genezing te zoeken in Gilead, dat vanouds een reputatie op dit gebied had. Deze ironie grenst aan cynisme, omdat Egypte in de oudheid zelf bekend stond om zijn medische vaardigheden. Tegelijk wordt in de derde strofe (46:11-12) aangegeven dat deze wanhoopspoging op niets zal uitlopen, Egypte is reddeloos verloren. In plaats daarvan dat Egypte's legers de aarde overdekken (46:9), vervult Egypte's smaad de aarde (46:11). De mare van deze ondergang gaat de wereld in...

Jeremia 46:3-12 vormt een doordachte literaire eenheid met een grote zeggingskracht. Op levendige wijze visualiseert de profetie het momentum in de wereldgeschiedenis van die dagen: de Nijl wordt bij de Eufraat gekeerd, Egypte door Babel verslagen - maar de ware Tegenstander is JHWH zelf. Dit laatste wordt pas in 46:10, het kernvers van de profetie, duidelijk. 
BOX 1: Detailexegese van Jeremia 46:10.

\begin{tabular}{|c|c|c|}
\hline 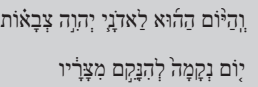 & $\begin{array}{l}(10 a A) \\
(10 a B)\end{array}$ & $\begin{array}{l}\text { Maar die dag is voor de Heer, JHWH van } \\
\text { alle machten, }\end{array}$ \\
\hline 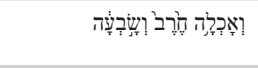 & $(10 b A)$ & $\begin{array}{l}\text { een dag van wraak om zich te wreken op } \\
\text { zijn tegenstanders; }\end{array}$ \\
\hline 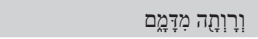 & $(10 \mathrm{bB})$ & het zwaard verslindt tot verzadiging toe, \\
\hline 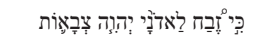 & $(10 c A)$ & en het wordt dronken van hun bloed - \\
\hline 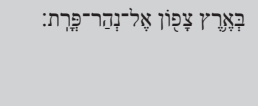 & $(10 c B)$ & $\begin{array}{l}\text { want de Heer, JHWH van alle machten, } \\
\text { houdt een offermaal in } \\
\text { het land van het noorden, bij de rivier de } \\
\text { Eufraat. }\end{array}$ \\
\hline
\end{tabular}

\section{Detailexegese van Jeremia 46:10 Jeremia 46:10aA-B}

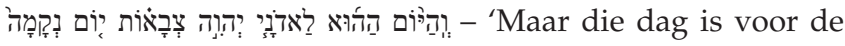
Heer, JHWH van alle machten, een dag van wraak ...'

In de tweede strofe van de profetie brengt Jeremia 46:10 na de verzen 7-9 dezelfde onverwachte perspectiefwisseling als in de eerste strofe van de profetie Jeremia 46:5-6 dat doet na de verzen 3-4. ${ }^{2}$ Het ene moment volgt de hoorder/lezer de voorbereiding voor de strijd en ziet hij het leger krijgsvaardig afmarcheren, het andere moment krijgt hij het beeld voor ogen van een slagveld waar ditzelfde leger bliksemsnel aan zijn einde komt. Waar 46:5-6 deze nederlaag met een waarom-vraag en een beschouwing over de onontkoombaarheid van dat einde aangeven, wordt in 46:10 deze nederlaag verbeeld met het woordveld 'wraak-zwaardbloed-offermaal', inclusief een theologische belichting. Op deze wijze biedt de tweede strofe 46:7-10 een tweevoudige verdieping van de eerste strofe 46:3-6. Ten eerste wordt de identiteit van het opmarcherend leger onthuld (vss 7-9) en ten tweede wordt de onverwachte nederlaag in het juiste licht gesteld (vers 10). Het slagveld waarnaar het Egyptische leger triomfantelijk optrekt, wordt een slachtbank. De vijand voor wie Egypte moet zwichten is in wezen niet Babel - deze naam wordt niet eens genoemd - maar JHWH zelf.

Formeel en inhoudelijk wijkt 46:10 duidelijk af van de voorgaande verzen, die een heel andere stijl hebben. Het is echter nog niet zo eenvoudig om te bepalen of 46:10 proza of poëzie is (Watson 1984:382). Opvallend is de uitgebreide syntaxis: een envelopconstructie met twee samengestelde nominale zinnen (46:10a en 46:10c) en in het centrum een verbale zin die uit drie elementen bestaat $(46: 10 \mathrm{~b})$. Bepalend is het klankpatroon met achtmaal een a-klank. Inhoudelijk biedt 46:10 een interpretatie van de slag bij Karkemiš met gebruikmaking van diverse traditionele voorstellingen en beelden: 'de dag van JHWH', 'de wraak Gods', 'het zwaard dat verslindt en dronken wordt', 'de offermaaltijd'. Groot is de verwantschap met teksten als Jesaja 34:1-8, Ezechiël 39:17-20, Zefanja 1:7-9. De traditie-historische vraag welke tekst origineel en welke ontleend is, hangt uiteraard af van de datering van de verschillende geschriften. Met name de relatie met Jesaja 34 komt in de commentaren aan de orde, zonder een definitieve oplossing van de vraag hoe deze relatie precies geïnterpreteerd dient te worden (Snaith 197:23-24; Huwyler

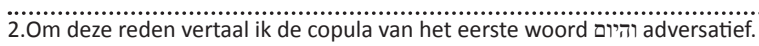

1997:97; Allen 2008:464; Fischer 2005:474; Lundbom 2004:202). We mogen ervan uitgaan dat profeten vrijelijk uit zowel mondelinge als schriftelijke tradities hebben geput om hun woorden vorm te geven, zonder dat steeds van een specifieke afhankelijkheidsrelatie sprake hoeft te zijn. Dat lijkt ook met Jeremia 46:10 het geval te zijn.

Sommige exegeten zijn van mening dat het eerste deel van 46:10 secundair moet zijn. Volz beschouwt vers 10a als een storende glos (1928:396, voetnoot 2) en volgens Duhm heeft de schrijver van vers 10a er geen idee van hoe sterk hij hier van de inzichten van de profeet Jeremia afwijkt (1901:338). Meestal wordt een 'Aufforderung zum Kampf' (zie vers 9) ook direct gevolgd door een met het partikel כי ingeleide motivering. Dat vers 10a de samenhang tussen vers 9 en de כ-zin in vers 10c echter niet stoort, wordt door Bach overtuigend aangetoond (1962:79; vgl. Lutz 1968:136). Rudolph (BHS) stelt voor om צבאות in vers 10a metri causa te

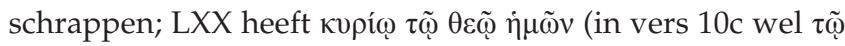
אטpí $\sigma \alpha \beta \alpha \omega \theta) .{ }^{3}$ Bright meent dat לאדני moet worden weggelaten (1965:306); Hay wil heel vers 10 schrappen vanwege het late 'apocalyptische' karakter (1960:116). Deze voorstellen hebben terecht weinig navolging gekregen. Het is waar dat 46:10 met de herhaling van לאדני יהוה צבאות een enigszins overladen indruk maakt, maar dit kan goed een bewuste retorische techniek zijn (Brueggemann 1998:459; pace Holladay 1989:318, die meent dat vers 10a breekt met de stijl van de profetie). Op deze wijze wordt het grote belang van dit vers geaccentueerd, en het gebeuren rond de slag bij Karkemiš in een helder theologisch licht gezet. Hier ligt de quintessens van de gehele profetie: bij het handelen van de enige Tegenstander met wie farao Neko niét had gerekend.

De Masoretische accentuering scheidt vers $10 \mathrm{aA}$ met een rvia' van vers $10 \mathrm{aB}$, maar het is syntactisch gezien goed mogelijk vers $10 \mathrm{aB}$ als predikaat direct bij vers $10 \mathrm{aA}$ te nemen: 'Deze dag is voor de Heer een dag van ...'. De woorden היום ההוא herinneren aan het bekende profetische thema van 'de dag van JHWH'. In Jeremia wordt de standaarduitdrukking יום יהוה zelf niet gevonden, maar inhoudelijk sluit היום ההוא in 10aA naadloos bij deze voorstelling aan. De prediking van יום יהוה heeft bij de profeten verschillende vormen aangenomen; stellig gaat het niet om één enkele, universele, toekomstige gerichtsdag (zie de korte Forschungsüberblick in TWAT 3,583-584). De יום יהוה vormde 'a powerful concept available to the prophets for their use in interpreting various momentous events - past, future or imminent' (Everson 1974:335). De kern van deze voorstelling is dat God het initiatief heeft en bij machte is in te grijpen in de geschiedenis van zijn volk en van deze wereld. Dat is ook het geval in het jaar 605 v.Chr., bij de Eufraat: deze dag waarop de wereldgeschiedenis kantelt doordat Babel Egypte verslaat, is in profetisch perspectief een gerichtsdag van Godswege. Dit wordt onderstreept door de herhaalde volle benaming אדני יהוה צבאות, hier vertaald met 'de Heer, JHWH van alle machten' (zo ook in Jer 2:19; 49:5; 50:25, 31). LXX 3.Janzen spreekt hier van een 'inner-Greek addition' (1973:82; vgl. ook Stipp 1994:54). 


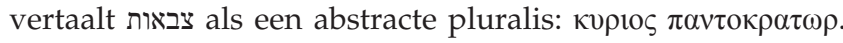
Het epitheton צבאות duidt Gods verhevenheid boven alle hemelse en aardse machten aan, bij uitstek passend in de context van strijd (TWAT 6,876-892; HAL 934-935; DCH 5,66-67; Ges.18 1098; THAT 2,502-507).

\section{Jeremia 46:10aB}

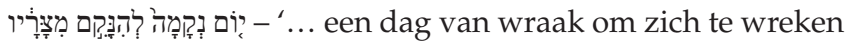
op zijn tegenstanders.'

De gerichtsdag wordt in vers $10 \mathrm{aB}$ gekarakteriseerd als 'een dag van wraak'. De wortel נקם heeft een sterk juridisch koloriet en wordt in het Oude Testament geregeld verbonden met de oorlogsvoering. De 'wraak' van JHWH is een vergeldende en rechtsherstellende actie van God als Koning, Krijgsheer en Rechter. In tegenstelling tot de negatieve connotaties van het moderne woord 'wraak' is voor de oudtestamentische notie van de wraak kenmerkend 'the legitimate power to act' (Peels 1995:275: 'the root נקם includes the thought of legitimate and appropriate authority'). De oudtestamentische verkondiging aangaande de wraak van JHWH kan als volgt worden samengevat: 'The punishing retribution of God, who in kingly sovereignty - faithful to his covenant - judging and fighting arises to defend the honour of his name, insures the maintenance of this justice and works for the liberation of his people' (Peels 1995:277). De uitdrukking 'dag van de wraak' (יום נקמה) ziet op zich niet op een speciale dag of gefixeerde datum, maar meer in het algemeen op de tijd of het tijdstip waarop het oordeel komt. In deze woordverbinding ligt het accent niet zozeer op het temporele, maar op de (verwachte) actie. 'Der Begriff "Tag“ umschreibt [in zulke genitief-verbindingen, HGLP] den Ereignis- und Geschichtscharakter eines machtvollen Geschehens und seine Wirkungen' (Herrmann 1965:121).

De 'dag van de wraak' wordt geëxpliciteerd met het finale zinsdeel להנקם מצריו (prepositie + infinitivus constructus + object). Twee vragen zijn hierbij te stellen, met betrekking tot het object en de reden van Gods wraak. Wie zijn deze 'tegenstanders' (צריו)? De Targum leest met een toevoeging

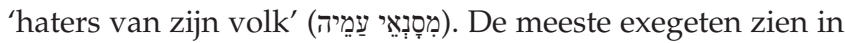
Egypte (Egypte's farao en leger) de tegenstander van JHWH, zoals in deze context goed past. Misschien bevat מצריו 'op zijn tegenstanders' zelfs een woordspeling op מִצרים 'Egypte' (Smothers 1995:292; Watson 1984:382; Carroll 1986:763), hoewel de woordcombinatie צר+מן+נקם vaker voorkomt (Nah 1:2, vgl. Jes 1:24, 59:17-18). De Jong meent dat onder de 'tegenstanders' van JHWH ook Juda zelf, c.q. de proEgyptische regering te Jeruzalem, is te rekenen (1978:106-108, zo ook Smothers 1995:292; Lundbom 2004:202). De tekst van vers $10 \mathrm{aB}$ geeft zelf niet een specifieke identificatie maar bevat een algemene uitspraak: JHWH wreekt zich op zijn tegenstanders. Plaats en persoon komen pas in 46:10c in beeld, met een verwijzing naar de precieze locatie.

Met het voorgaande zal samenhangen, dat de eigenlijke reden van de wraak van JHWH niet apart wordt aangegeven. Diverse exegeten menen dat de dood van Josia in/na de slag bij Megiddo in 609 en de daaropvolgende dominantie van Egypte over Juda (inclusief het afzetten en wegvoeren van Joahaz naar Egypte) de verklaring is van de wraak van JHWH in vers 10a (zo reeds Kimchi). Jeremia klaagde immers om Josia's dood (2 Kron 35:25) en Joachaz' wegvoering naar Egypte (Jer 22:10-12)? Aan deze klacht paart zich dan nu het verlangen naar wraak. Wraak, want Egypte heeft zich door deze daden immers vergrepen aan het volk van JHWH! Zal de Koning de verdrukte vazal niet willen en moeten wreken? De context zelf geeft echter geen aanleiding voor deze redenering; Israël wordt zelfs in het geheel niet genoemd. ${ }^{4}$ Een tweede gedachte is om Gods wraak in Jeremia 46:10 te koppelen aan het feit dat Egypte het voornemen van JHWH met de Chaldeeën (vgl. Jer 25:11,27:6-11) poogt te verhinderen (Wambacq 1957:261; Seidl 2009:654). Als Babel immers het goddelijk strafinstrument is, heeft ieder die zich tegen Nebukadnezar verzet Gods toorn te duchten. Beter is een derde voorstel, om de reden van Gods wraak te zoeken in Egypte's hoogmoedige en verderf zaaiende greep naar de wereldmacht (vgl. Jes 47). De wraak van JHWH treft de arrogantie van de macht, de hybris van Egypte (Weiser 1956:391; Allen 2008:463-464; Fohrer 1981:51; Höffken 1977:266; Peels 1995:180). De tekst van 46:10aB zelf is echter non-specifiek, in tegenstelling tot bijvoorbeeld het wraakmotief in Jeremia 51:11 ('de wraak voor zijn tempel'). In Jeremia 46:3-12 worden schuld en straf niet gethematiseerd. Het vers bevat als het ware een algemene belijdenis, die in vers $10 \mathrm{aA}$ en vers $10 \mathrm{~b}$ wordt toegepast op een concrete situatie. In zijn algemeenheid zet vers 10a de slag bij Karkemiš in het licht van het universele oordeel van JHWH, die de aarde gemaakt heeft (Jer 27:5), die een 'rîb' heeft met alle volken (Jer 25:31) en gericht houdt over al wat leeft (Jer 45:5). In de bundel volkenprofetieën is Egypte de eerste natie die hiermee geconfronteerd wordt.

\section{Jeremia 46:10b-c}

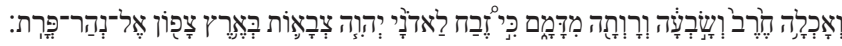
- '... het zwaard verslindt tot het helemaal verzadigd is, en het wordt dronken van hun bloed - want de Heer, JHWH van alle machten, houdt een offermaal in het land van het noorden, bij de rivier de Eufraat.'

Wat de wraak van JHWH concreet teweegbrengt, wordt in 46:10b-c met het huiveringwekkende beeld van een offermaaltijd uitgewerkt. ${ }^{5}$ De plaats waar de offers geslacht worden is het slagveld bij de Eufraat; de offers die gebracht worden zijn de Egyptische soldaten; de gast aan de maaltijd is het zwaard van God dat eet en drinkt totdat het verzadigd is. Ten onrechte spreekt Kalmanofski over 'divine cannabalism' in deze tekst: 'the sword is the utensil that feeds God' (2008:57). Het is echter het zwaard zelf dat 'eet', niet God. זבח is de technische term voor een slachtoffer, en wordt ook voor de offermaaltijd of het offerfeest gebruikt waarbij

4.Tegen deze uitleg pleit ook 2 Kronieken $35: 20-25$ (de dood van Josia is het gevolg van zijn onwil te luisteren naar het woord van JHWH dat via farao Neko tot hem komt). Zie ook de kritiek bij Huwyler (1997:99).

5.Dit beeld valt weg in Targum Jonathan, die 'doden', 'slaughter' leest. Vergelijk echter ook 2 Kon 23:20 (Josia 'slacht' de priesters in de steden van Samaria). 
het offerritueel volbracht wordt en (delen van) de geofferde dieren gegeten (TWAT 2,509-531; NIDOTTE 1,1066-1073). In dezelfde context van een gerichtshandeling van JHWH aan vijandige naties wordt deze metafoor van het offerfeest toegepast in Jesaja 34:6, Ezechiël 39:17 en Zefanja 1:7. Vooral met Jesaja 34 is veel overeenkomst (ofschoon er ook verschillen zijn, zie Snaith 1971:23-24): het zwaard dat dronken wordt van bloed, de wraak van JHWH, een specifieke locatie.

De aan deze maaltijd genodigde gast is 'het zwaard' (חרב). Voor het beeld van het zwaard dat eet (אכל) zie Deuteronomium 32:42, 2 Samuël 2:26, Jesaja 31:8, Jeremia 2:30, Hosea 11:6, Nahum 2:14. Sprekend is ook de uitdrukking 'de mond van het zwaard' (פי חרב). De combinatie eten-verzadigd worden wordt in Jeremia steeds letterlijk gebruikt, metaforisch alleen hier in 46:10 voor het zwaard dat eet en verzadigd (שבע) wordt. De enige parallel voor het 'zwaard dat dronken wordt' (רוה 'drink one's fill', DCH 7,426; 'sich satt trinken', HAL 1115; Ges.18 1224) is Jesaja 34:5 (en vgl. Jesaja 34:7). Het zwaard is het gerichtsinstrument van JHWH (Jer 12:12, 47:6, 49:37, cf.

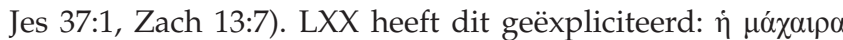
אטpíov - is in MT na חֶרב een suffix 1 door haplografie weggevallen (BHS, Carroll 1986:763), of heeft LXX willen verduidelijken door onderscheid te maken met de in vers 9 genoemde wapens (Lundbom 2004:202)?

In vers $10 \mathrm{cB}$ wordt tenslotte de plaats van handeling genoemd. De formulering varieert licht bij die van de verzen 2 en 6 . Het 'Noorderland' (ארץ צפון) is een collocatie die alleen bij de profeten Jeremia en Zacharia voorkomt; 46:6 heeft korter צפונה. De precieze locatie wordt aangewezen: אל־נהר־פרת bij de rivier de Eufraat, met andere woorden: bij Karkemiš. Dat in 46:2 bij deze localisering de prepositie על gebruikt wordt en hier in 46:10 de prepositie אל heeft geen bijzondere betekenis; vaker alterneren deze twee preposities zonder inhoudelijk verschil (vooral in Jer en Ez; cf. HAL 49).

\section{Theologische evaluatie}

In het jaar 605 v.Chr. wordt bij Karkemiš definitief een einde gemaakt aan Egypte's ambities, en daarmee ook aan de 'balance of power' die na de ondergang van het NieuwAssyrische wereldrijk in 609 v.Chr. ontstond tussen de macht van het land van de Nijl en die van het land van de Eufraat en de Tigris. Onstuitbaar zal hierna de Babylonische opmars zijn, tot aan de grenzen van Egypte. Juda is tot dit moment nog vazal van Egypte, en aan het hof van Jeruzalem overheerst onder koning Jojakim - die door farao Neko zelf is aangesteld - de pro-Egyptische partij. De vraag welke koers Juda nu verder moet varen is brandend actueel. Het is duidelijk wat Jeremia met zijn profetische interpretatie van de slag bij Karkemiš beoogt te prediken: op Egypte valt geen enkele staat te maken. Egypte is compleet verslagen door de grootst denkbare tegenstander: JHWH. Wie toch op Egypte vertrouwen wil, keert zich tegen de God van Israël zelf. In en achter het politieke gebeuren van die dagen ontvouwt zich het gericht van JHWH tegen al wat leeft, en zijn oordeel is niet te keren.
De theologische boodschap van de eerste profetie over Egypte ligt in het thema van de wraak van God. JHWH maakt een einde aan de arrogantie van de macht en stuit de oeverloze ambities van het land van de Nijl. Hij komt als Rechter om de zaken recht te trekken. Dit brengt de grote omkeer teweeg: van de trots die verandert in schaamte, van de machtswellust die eindigt in een wilde vlucht, van de zelfverheffing die resulteert in een totale val. In 46:10 wordt in het heftige beeld van het verslindend zwaard duidelijk gemaakt dat niet Egypte de wereld regeert (zie de pretentie van Egypte in 46:8), maar JHWH, de Heer van alle machten. De hoogmoed van de wereldveroveraar wordt door de Rechter en Heerser der wereld afgestraft. Niet alleen in de profetie tegen Egypte, maar ook elders in Jeremia's volkerenprofetieën wordt op soortgelijke wijze benadrukt dat Hij regeert en een rechtsclaim op de volken heeft. De God van Israël is de God van de gehele aarde (Jer 27:5). Tegenover Hem hebben allen rekenschap af te leggen; Hij heeft een 'rîb' met de volken (Jer 25:31). De wraak van God tegen de volkeren, die meestentijds in het kader van de 'rîb' van Sion staat (zie bijvoorbeeld Jes 34:8), krijgt in Jeremia 46:10 nog grotere dimensies: de rechtsstrijd van de Schepper met zijn schepselen. Gods universele heerschappij maakt door zijn wraak een einde aan de machtswellust. Hij laat de verwoesting (46:8) niet straffeloos passeren.

In de bundel volkenprofetieën in Jeremia 46-51 neemt de prediking van de wraak van God een belangrijke plaats in (zie hierover verder Peels 1995:176-177). Zowel de eerste als de laatste profetie in deze bundel spreekt over de dag of de tijd der wrake. De eerste profetie (46:2-12) in de bundel is tegen Egypte gericht, de laatste (50:1 - 51:58) tegen Babel: de twee grootmachten van de toenmalige wereld. Door de wraak van God worden deze machten, die beide op brute wijze de wereldheerschappij nastreven (vergelijk 46:8 met $51: 25,49,53)$, zozeer geraakt dat er geen genezing meer is (46:11 - 51:8-9). De bundel Jeremia 46-51 opent met een profetie over de wraak Gods die gedateerd is en in het verleden ligt; de bundel eindigt met een profetie over de wraak Gods die in de nabije toekomst ligt. Net zo zeker als God in het verleden Egypte met zijn wraak confronteerde (begin van de bundel), zal Hij dat in de toekomst met Babel doen (eind van de bundel). Niet aan een van hen, maar aan Hem is de wereldheerschappij. Dit mag het volk van JHWH weten, dit volk dat in Jeremia's dagen tussen de hamer van Egypte en het aambeeld van Babel kwam te liggen, en daaraan tenonderging. De wraak van God reikt echter verder, en baant een weg naar de toekomst.

\section{Erkenning Tegenstrijdige belangen}

De auteur verklaart geen financiële of persoonlijke belangen te hebben die hem ongepast kunnen hebben beïnvloed bij het schrijven van dit artikel.

\section{Literatuurverwijzingen}

Allen, L.C., 2008, Jeremiah: A commentary, Westminster John Knox Press, Louisville, KY. (Old Testament Library). 
Bach, R., 1962, Die Aufforderungen zur Flucht und zum Kampf im alttestamentlichen Prophetenspruch, Neukirchener Verlag, Neukirchen. (WMANT 9).

Bourguet, D., 1987, Des métaphores de Jérémie, Gabalda, Paris. (Etudes Bibliques 9).

Bright, J., 1965, Jeremiah, Doubleday, Garden City, NY. (The Anchor Bible).

Brueggemann, W., 1998, A commentary on Jeremiah: Exile and homecoming, Eerdmans, Grand Rapids, MI.

Carroll, R.P., 1996, Jeremiah, SCM, London. (Old Testament Library).

De Jong, C., 1978, De volken bij Jeremia: Hun plaats in zijn prediking en in het boek Jeremia, PhD thesis, Theologische Universiteit, Kampen.

Duhm, B., 1901, Das Buch Jeremia, Mohr, Tübingen. (Kurzer Handcommentar zum Alten Testament).

Everson, A.J., 1974, 'The days of Yahweh', Journal of Biblical Literature 93, 329-337.

Fischer, G., 2005, Jeremia, Band 2: Kap. 26-52, Herder, Freiburg im Br. (Herders Theologische Kommentar zum Alten Testament).

Fohrer, G., 1981, 'Vollmacht über Völker und Königreiche (Jer 46-51)', in id., Studien zu alttestamentlichen Texten und Themen (1966-1972), pp. 44-52, De Gruyter, Berlin. (BZAW 155).

Fretheim, T., 2002, Jeremiah, Smith \& Helwys Pub., Macon GA. (Smyth \& Helwys Bible Commentary).

Herrmann, S., 1965, Die prophetischen Heilserwartungen im Alten Testament: Ursprung und Gestaltwandel, Kohlhammer, Stuttgart. (BWANT 85).

Hay, L.C., 1960, The oracles against the foreign nations in Jeremiah 46-51, PhD thesis, VanderBilt University, Nashville, TN.

Holladay, W.L., 1989, Jeremiah 2: A commentary on the book of the prophet Jeremiah chapters 26-52, Fortress Press, Minneapolis, MN. (Hermeneia).

Höffken, P., 1977, 'Zu den Heilszusätzen in der Völkerorakelsammlung des Jeremiabuches. Zugleich ein Beitrag zur Frage nach den Überlieferungsinteressen an den Völkerorakelsammlungen der Prophetenbücher', Vetus Testamentum 27, 398-412.

Huwyler, B., 1996, 'Jeremia und die Völker: Politische Prophetie in der Zeit der babylonischen Bedrohung (7./6. Jh. v. Chr.)', Theologische Zeitschrift 52, 193-205.

Huwyler, B., 1997, Jeremia und die Völker: Untersuchungen zu den Völkersprüchen in Jeremia 46-49, Mohr Siebeck, Tübingen. (FAT 20).

Hyatt, J.P., 1956, 'The book of Jeremiah', Abingdon, Nashville, TN. (The Interpreter's Bible).

Jackson, J.J., 1993, 'Jeremiah 46: Two oracles on Egypt', Horizons in Biblical Theology $15,136-144$.

Janzen, J.G., 1973, Studies in the text of Jeremiah, Harvard University Press, Cambridge, MA.

Jones, D.R., 1992, Jeremiah, Eerdmans, London. (New Century Bible).

Kalmanofsky, A., 2008, Terror all around: The rhetoric of horror in the book of Jeremiah, T\&T Clark, New York.
Keown, G.L., Scalise, P.J. \& Smothers, T.G., 1995, Jeremiah 26-52, Word Books Publisher, Dallas. (WBC 27).

Kessler, R., 2002, Die Ägyptenbilder der Hebräischen Bibel: Ein Beitrag zu neueren Monotheismusdebatte, Katholisches Bibelwerk, Stuttgart. (SBS 197).

Lipschits, O., 2005, The fall and rise of Jerusalem: Judah under Babylonian rule, Eisenbrauns, Winona Lake.

Lundbom, J.R., 2004, Jeremiah 37-52: A new translation with introduction and commentary, Doubleday, New York. (The Anchor Bible).

Lutz, H.-M., 1968, Jahwe, Jerusalem und die Völker: Zur Vorgeschichte von Sach 12, 1-8 und 14, 1-5, Neukirchener Verlag, Neukirchen-Vluyn. (WMANT 27).

Maier, M.P., 2002, Ägypten - Israels Herkunft und Geschick: Studie über einen theopolitischen Zentralbegriff im hebräischen Jeremiabuch, Lang, Frankfurt am Main. (Österreichische Biblische Studien 21).

Peels, H.G.L., 1995, The vengeance of God: The meaning of the root NQM and the function of the NQM-texts in the context of divine revelation in the Old Testament, Brill, Leiden. (OTS 31).

Redford, D.B., 1992, Egypt, Canaan, and Israel in ancient times, Princeton University Press, Princeton, NJ.

Rudolph, W., 1968, Jeremia, Mohr

Siebeck, Tübingen. (Handbuch zum Alten Testament).

Seidl, Th., 2009, 'Carchemish in Near Eastern historiography and in the Old Testament', Old Testament Essays 22, 646-661.

Snaith, J.G., 1971, 'Literary criticism and historical investigation in Jeremiah Chapter XLVI', Journal of Semitic Studies 16, 15-32.

Stipp, H.-J., 1994, Das masoretische und alexandrinische Sondergut des Jeremiabuches. Textgeschichtlicher Rang, Eigenarten, Triebkräfte, Vandenhoeck \& Ruprecht, Göttingen. (OBO 136)

Van der Westhuizen, J.P., 1991, 'A stylistic-exegetical analysis of Jeremiah 46:1-12', Jewish Bible Quarterly 20, 84-95.

Volz, P., 1922, Der Prophet Jeremia, Deichert, Leipzig. (Kommentar zum Alten Testament).

Wambacq, B.N., 1957, Jeremias, Romen \& zonen, Roermond. (Boeken van het Oude Testament).

Watson, W.G.E., 1984, Classical Hebrew poetry: A guide to its techniques, JSOT Press, Sheffield. (JSOTSup 26)

Weiser, A., 1981, Das Buch Jeremia, 8th edn., Vandenhoeck \& Ruprecht, Göttingen. (Das Alte Testament Deutsch).

Wiseman, D.J., 1956, Chronicles of Chaldaean kings (626-556 B.C.) in the British Museum, British Museum, London.

Wiseman, D.J., 1985, Nebuchadrezzar and Babylon, Oxford University Press, Oxford.

Woolley, C.L., 1921, Carchemish: Report on the excavations at Jerablus on behalf of the British Museum, Part II: The town defences, British Museum, London. 